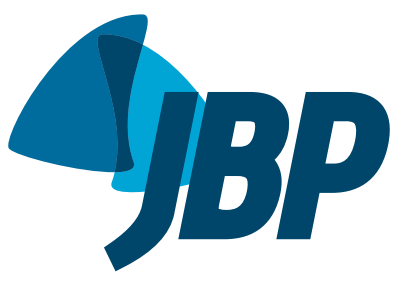

\title{
International collaboration among medical societies is an effective way to boost Latin American production of articles on tuberculosis
}

\author{
Giovanni Battista Migliori $i^{1, a}$, Rosella Centis ${ }^{1, b}$, Lia D’Ambrosio ${ }^{2, c}$, \\ Denise Rossato Silva, ${ }^{3, \mathrm{~d}}$, Adrian Rendon,e
}

1. Servizio di Epidemiologia Clinica delle Malattie Respiratorie, Istituti Clinici Scientifici Maugeri - IRCCS - Tradate Italia.

2. Public Health Consulting Group, Lugano, Switzerland.

3. Faculdade de Medicina, Universidade Federal do Rio Grande do Sul - UFRGS - Porto Alegre (RS) Brasil.

4. Centro de Investigación, Prevención y Tratamiento de Infecciones Respiratorias - CIPTIR - Hospital Universitario de Monterrey, Universidad Autónoma de Nuevo León -UANL Monterrey, México.

a. (iD) http://orcid.org/0000-0002-2597-574X

b. (D) http://orcid.org/0000-0002-8551-3598

c. (D) http://orcid.org/0000-0002-7000-5777

d. (ID http://orcid.org/0000-0003-0230-2734

e. (D) http://orcid.org/0000-0001-8973-4024

Submitted: 27 December 2018 Accepted: 10 January 2019.

Study carried out at the Centro de Investigación, Prevención y Tratamiento de Infecciones Respiratorias - CIPTIR

- Monterrey, México, and the WHO

Collaborating Centre For Tuberculosis and

Lung Diseases, Tradate, Italia.

\begin{abstract}
Objective: Most studies of tuberculosis originate from high-income countries with a low incidence of tuberculosis. A review of the scientific production on tuberculosis in Latin American countries, most of which are low- or middle-income countries (some with high or intermediate tuberculosis incidence rates), would improve the understanding of public health challenges, clinical needs, and research priorities. The aims of this systematic review were to determine what has been published recently in Latin America, to identify the leading authors involved, and to quantify the impact of international collaborations. Methods: We used PubMed to identify relevant manuscripts on pulmonary tuberculosis (PTB), drug-resistant tuberculosis (DR-TB), or multidrug-resistant tuberculosis (MDRTB), published between 2013 and 2018. We selected only studies conducted in countries with an annual tuberculosis incidence of $\geq 10,000$ reported cases and an annual MDR-TB incidence of $\geq 300$ estimated cases, including Brazil, Peru, Mexico, Colombia, and Argentina. Articles were stratified by country, type, and topic. Results: We identified as eligible 395 studies on PTB and 188 studies on DR/MDR-TB-of which $96.4 \%$ and $96.8 \%$, respectively, were original studies; $35.5 \%$ and $32.4 \%$, respectively, had an epidemiological focus; and $52.7 \%$ and $36.2 \%$, respectively, were conducted in Brazil. The recent Latin American Thoracic Association/European Respiratory Society/ Brazilian Thoracic Association collaborative project boosted the production of highquality articles on PTB and DR/MDR-TB in Latin America. Conclusions: Most of the recent Latin American studies on tuberculosis were conducted in Brazil, Mexico, or Peru. Collaboration among medical societies facilitates the production of scientific papers on tuberculosis. Such initiatives are in support of the World Health Organization call for intensified research and innovation in tuberculosis.
\end{abstract}

Keywords: Tuberculosis, pulmonary; Tuberculosis, multidrug-resistant; Latin America.

\section{INTRODUCTION}

The World Health Organization (WHO) has estimated that, in 2017, there were 9.0-11.1 million new cases of active tuberculosis and 1.2-1.4 million tuberculosisrelated deaths, indicating that tuberculosis is now the leading cause of infection-related death worldwide and is among the ten leading causes of death from any cause. ${ }^{(1)}$ The WHO Region of the Americas, which is managed by the Pan American Health Organization, includes the United States and Canada, both of which have a low incidence of tuberculosis, whereas the incidence of tuberculosis ranges from low to high in Latin American and Caribbean countries, which are mainly low- to middle-income countries with limited resources allocated to health care and research. ${ }^{(1,2)}$

Scientific societies such as the Asociación Latinoamericana de Tórax (ALAT, Latin American Thoracic Association) and the Sociedade Brasileira de Pneumologia e Tisiologia (SBPT, Brazilian Thoracic Association) are both active in promoting training, continued medical education, and research that is useful in the fight against tuberculosis. The influence of those societies reaches most of the countries in Latin America. Recently, they have joined forces with the European Respiratory Society (ERS) to develop initiatives against tuberculosis in several fields, including research. ${ }^{(3,4)}$ Such initiatives are collectively known as the ALAT/ERS/SBPT project. Because no specific funds were otherwise available for the task, the project included data collection, the creation of new databases, the ordering of existing databases, and the design of studies, as well as the writing/translation of the articles produced and the facilitation of their submission to peer-reviewed journals.

As clearly mentioned by the WHO and included in Pillar 3 of its "End TB Strategy", ${ }^{(5,6)}$ research is crucial to promoting better clinical and public health initiatives. 
By reviewing who and what has recently been published in Latin America on the subject of active tuberculosis and measuring the impact of international collaboration on the production of scientific evidence, we could gain a better understanding of what aspects should be targeted in order to address the WHO recommendations.

For the purposes of this article, we included five of the six Latin American countries that report more than 10,000 cases of tuberculosis annually. Those countries are, in decreasing order of tuberculosis incidence, Brazil, Peru, Mexico, Colombia, and Argentina. ${ }^{(1-4)}$ Collectively, they reported a total of 160,683 cases in 2016, as shown in Table S1 of the supplementary file (available online at http://jornaldepneumologia. com.br/detalhe_anexo.asp?id=60).

Countries approaching the goal of tuberculosis elimination (defined as less than 1 case per million population) need to focus on specific interventions such as managing latent tuberculosis infection, and countries with a higher tuberculosis incidence need tuberculosis control activities focused on active pulmonary tuberculosis (PTB). $\cdot^{(3,4,7-9)}$ Therefore, we decided to limit our review to articles dealing with active tuberculosis.

The epidemiological diversity of Latin American countries was recently captured in two important documents related to the region, both published jointly by the Pan American Health Organization and the WHO: the 2013 Strategic Plan of the Pan American Health Organization ${ }^{(10)}$; and the 2014 Plan of Action for the Prevention and Control of Tuberculosis. ${ }^{(11)}$ It is expected that research priorities will be aligned with the priorities and resources available in each country. The Brazilian National Plan to End Tuberculosis as a Public Health Problem is an example of that. ${ }^{(12)}$ Further new information emerging from local studies is needed in order to increase the overall scientific production in Latin America.

The primary aim of this review was to identify the main areas of tuberculosis research conducted in the Latin American countries with the highest rates of active PTB, drug resistant-tuberculosis (DR-TB), and multidrug-resistant tuberculosis (MDR-TB). Secondary aims were to identify the Latin American researchers leading the production of tuberculosis research and to evaluate the impact that recent international collaborations among medical societies have had on the overall scientific output in the region.

\section{METHODS}

This study focused on the local scientific contributions of Brazil, Peru, Mexico, Colombia, and Argentina related to PTB and MDR-TB. Those five countries, all of which are middle-income countries, have the highest scientific production rates in Latin America. In each of those countries, the annual tuberculosis incidence is $\geq 10,000$ reported cases and the annual MDR-TB incidence is $\geq 300$ estimated cases, as shown in Table S1 of the supplementary file (available online at http://jornaldepneumologia.com.br/detalhe_anexo. asp?id=60). Those are also the only countries that have participated in the ALAT/ERS/SBPT project.

Although Haiti ranks fourth in Latin America in terms of the incidence of tuberculosis, we decided not to include it in the regional analysis of this review, for a number of reasons. As a low-income country, Haiti receives long-term external financial support for research (mainly from United States government agencies). In addition, Haiti has not been involved in any studies related to the ALAT/ERS/SBPT project. Those two conditions would make it difficult to evaluate the spontaneous research contribution of the country.

\section{Inclusion criteria}

We selected peer-reviewed articles written in English, Spanish, or Portuguese by authors (corresponding authors or not) working in any of the five Latin American countries under study (Brazil, Peru, Mexico, Colombia, and Argentina). We used PubMed to identify any relevant manuscripts, published between January 1, 2013 and April 19, 2018, authored by Latin American researchers. To attribute a given article to a given country, the first selection criterion was the country of the corresponding author, followed by that of the first author and then that of each of the other authors, based on the affiliations as they appeared in the original manuscript. Manuscripts with authors whose main affiliation was in a high-income country (e.g., the United States, Canada, or a country in Europe) were not considered if no Latin American affiliations were listed.

We performed our searches in two steps, using the following search terms: "pulmonary tuberculosis" OR "pulmonary TB", to retrieve articles related to PTB (step 1); and "multidrug-resistant tuberculosis" OR "multidrug-resistant TB" OR "MDR-TB" OR "drugresistant tuberculosis" OR "drug-resistant TB", to retrieve articles specifically focused on DR/MDR-TB (step 2). Most of the MDR-TB-related manuscripts were retrieved in the first step. Articles related to extrapulmonary tuberculosis were excluded, because the focus of this review was to identify the scientific production related to the transmissible form of tuberculosis (drug-susceptible or drug-resistant PTB).

We included full-text original articles, review articles, editorials, letters, correspondence containing original data, and case reports containing new information. To ensure the quality of the publication, we included only articles that were published in journals that had an impact factor in the year of publication. Basic research studies were included if they involved patients with PTB. Case reports containing no new information were excluded, as were editorials/letters containing no original data.

Studies that were not related to the ALAT/ERS/ SBPT collaborative project were analyzed separately. We then drew comparisons between the articles that were related to the project and those that were not, 
those comparisons being limited to articles published in 2016, 2017, or the first quarter of 2018.

\section{Data analysis}

The articles were first separated into two groups: those related to PTB; and those related to DR/MDR-TB. They were then stratified by country and type of manuscript-articles containing original data (full manuscripts, short reports, or letters), editorials, and review articles-as well as by topic (epidemiology/ research, biochemistry/diagnosis, treatment/outcomes, or genetics/immunology/vaccines). Two of the authors, working independently, evaluated the manuscripts. Any disagreements were resolved by consensus.

For each country, the authors publishing the most articles, either on PTB or on DR/MDR-TB, were identified. For each of those authors, a complete bibliometric analysis was performed, including the overall number of publications, the $\mathrm{h}$-index, and the number of citations. The articles related to the ALAT/ ERS/SBPT project (and therefore their authors) were not considered in the main analysis, although they were considered in the comparative analysis. The study was conducted in accordance with the 2009 Preferred Reporting Items for Systematic Reviews and Meta-Analyses guidelines. ${ }^{(13)}$

\section{RESULTS}

For the period from January 2013 to April 2018, a total of 803 manuscripts were identified (Figure 1): 532 on PTB and 271 on DR/MDR-TB. Of those 803 manuscripts, 583 were deemed eligible for further analysis: 395 on PTB and 188 on DR/MDR-TB.

Of the 395 articles on PTB, 137 were excluded, for the following reasons (Figure $1 \mathrm{~A}$ ): being a case report or letter containing no new information $(n=45)$; being authored by individuals not working in one of the Latin American countries specified $(n=34)$; not focusing on tuberculosis $(n=25)$; and having been published in a journal that had no impact factor in the year of publication $(n=33)$. The annual number of articles on PTB unrelated to the ALAT/ERS/SBPT project was rather stable (Table 1): 60 in 2016; 90 in 2017; and 17 in the first quarter of 2018.

As can be seen in Figure $2 \mathrm{~A}$, the country contributing the greatest number of articles on PTB was Brazil, which accounted for $208(52.7 \%)$ of the 395 articles, followed by Mexico, with $79(20.0 \%)$, Peru, with 57 (14.4\%), Colombia, with $29(7.3 \%)$, and Argentina, with $22(5.6 \%)$. Table 2 describes the types of articles published in Latin America, the largest proportion being original studies, which accounted for $96.4 \%$ (381 articles). The most common topic studied in those articles was epidemiology/research (in 35.5\%), followed by genetics/immunology/vaccines (in $29.9 \%$ ), biochemistry/diagnosis (in 23.5\%), and treatment/ outcomes (in $11.1 \%$ ).

Of the 188 articles on DR/MDR-TB, 82 were excluded, for the following reasons (Figure 1B): being a duplicate or a case report/letter containing no new information ( $n=11)$; being authored by individuals not working in one of the Latin American countries specified ( $n=28$ ); not focusing on DR/MDR-TB or focusing on animal tuberculosis $(n=32)$; and having been published in a journal that had no impact factor in the year of publication $(n=12)$. The annual number of articles on DR/MDR-TB unrelated to the ALAT/ ERS/SBPT project was rather stable (Table 1): 32 in 2016; 41 in 2017; and 10 in the first quarter of 2018. As can be seen in Figure 2B, Brazil was the country contributing the greatest number of articles on DR/MDR-TB, accounting for $68(36.2 \%)$ of the 188 articles, followed by Peru, with $53(28.2 \%)$, Mexico, with $33(17.6 \%)$, Argentina, with $20(10.6 \%)$, and Colombia, with 14 (7.4\%). Table 2 shows that the largest proportion of articles on DR/MDR-TB were original studies, which accounted for $96.8 \%$ (182 articles). In terms of topics, the most common was epidemiology/research (in 32.4\%), followed by treatment/outcomes (in 30.9\%), biochemistry/ diagnosis (in $27.1 \%$ ), and genetics/immunology/ vaccines (in $9.6 \%$ ).

The bibliometric analysis of the top authors per country for the PTB and DR/MDR-TB categories are summarized in Table 3. For both categories, it is evident that the Brazilian Tuberculosis Research Network plays a leading role in Brazil, (14-19) whereas the Peruvian Partners in Health Research Network and Harvard University play major roles in Peru. ${ }^{(20-23)}$ In Argentina, Mexico, and Colombia, most of the basic research studies are conducted at a few high-level institutions, often in collaboration with other countries within and outside of Latin America.

Table 4 presents the comparative analysis of studies related and unrelated to the ALAT/ERS/SBPT project. A total of 289 articles were published in the comparison period (2016-2018). Studies related to the ALAT/ ERS/SBPT project accounted for $13.5 \%$ of those articles overall, specifically accounting for $9.7 \%$ of the articles on PTB and $20.1 \%$ of the articles on DR/ MDR-TB (Figure 3). All of those articles were published in journals with an impact factor. The contributions of the authors who published within the ALAT/ERS/ SBPT project are summarized in Table 5 .

\section{DISCUSSION}

The aims of this systematic review were to determine which were the main areas of research on PTB and DR/MDR-TB conducted recently in Brazil, Peru, Mexico, Colombia, and Argentina, to identify the Latin American authors involved in that research, and to quantify the impact of collaboration among international medical societies. It is difficult to evaluate the quantity and quality of the scientific production of the selected countries, because there is no benchmark or gold standard comparator.

In a recent bibliometric analysis, Sweileh et al. ${ }^{(24)}$ evaluated the studies on MDR-TB published worldwide 
Panel A) Pulmonary TB manuscripts
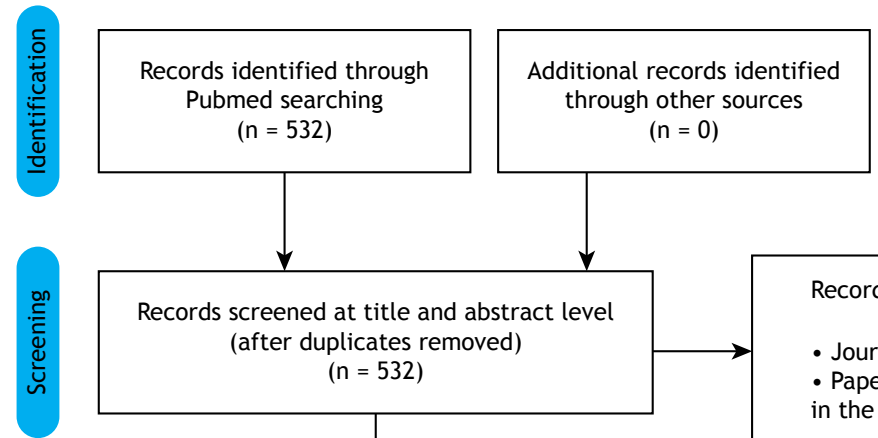

Records screened at title and abstract level (after duplicates removed) $(n=532)$

Records excluded at title and abstract level

$$
(n=67)
$$

- Journal without IF: $(n=33)$

- Papers published by AA not working

in the selected Countries: $(n=34)$

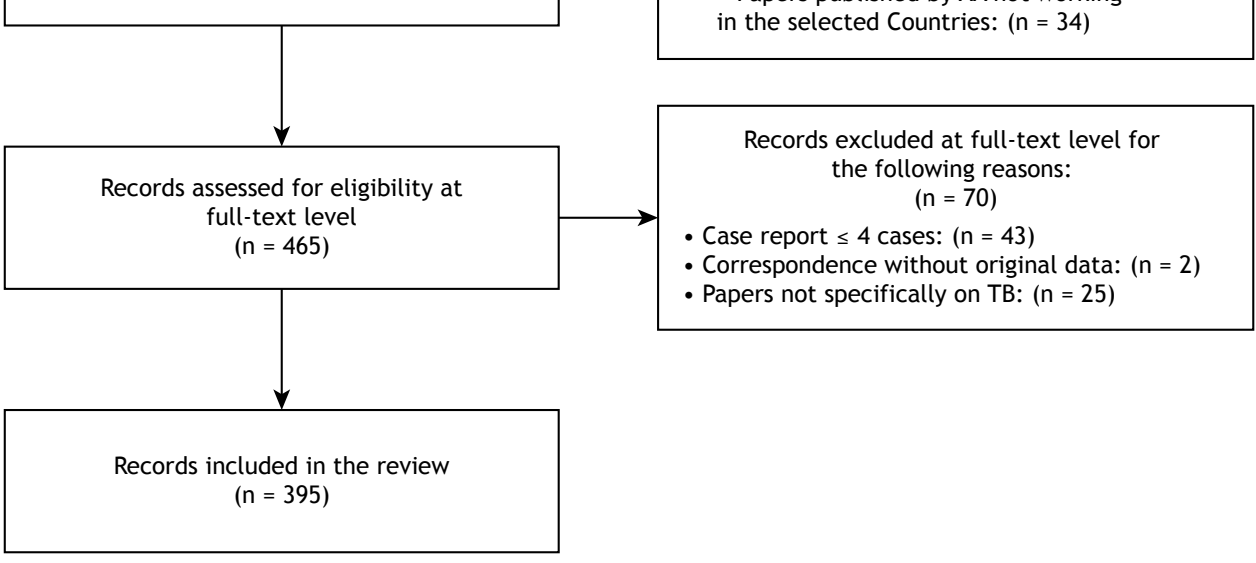

Panel B) DR/MDR-TB manuscripts
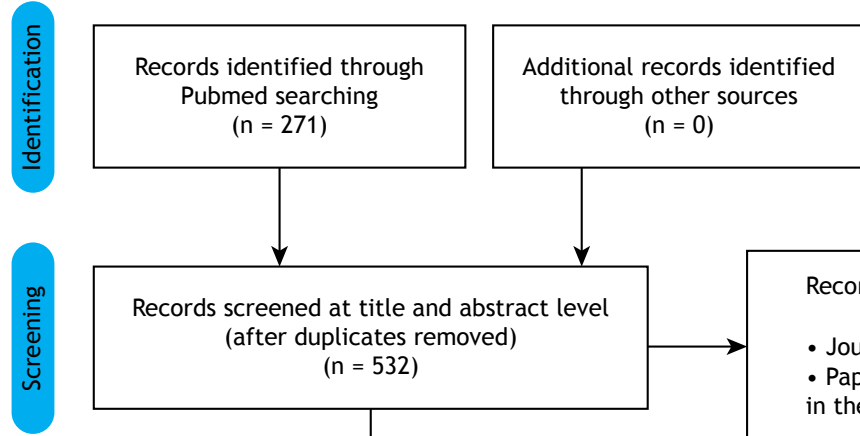

Records screened at title and abstract level (after duplicates removed) $(n=532)$

Records excluded at title and abstract level

$$
(n=40)
$$

- Journal without IF: $(n=12)$

- Papers published by AA not working

in the selected Countries: $(n=28)$

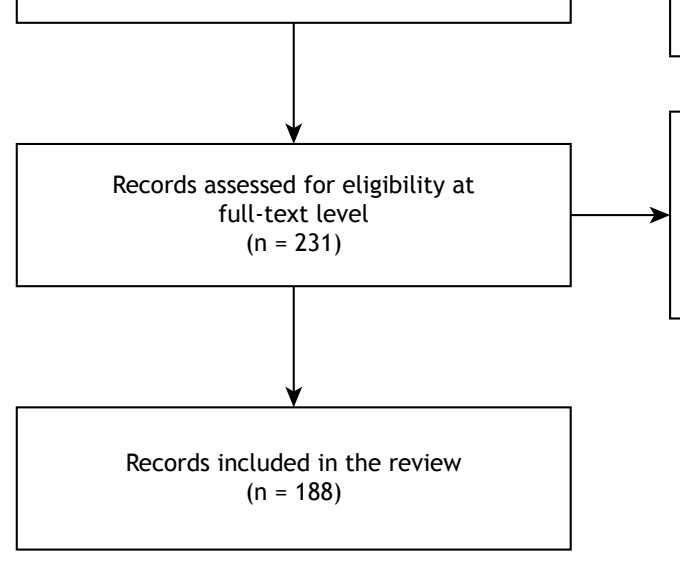

Records excluded at full-text level for the following reasons:

$$
(n=42)
$$

- Case report $\leq 4$ cases: $(n=9)$

- Correspondence without original data: $(n=1)$

- Papers not specifically on DR/MDR-TB: $(n=32)$

Figure 1. Preferred Reporting Items for Systematic Reviews and Meta-Analyses 2009 flow diagram of the process of selecting manuscripts on pulmonary tuberculosis (TB, panel A) and on drug-resistant/multidrug-resistant tuberculosis (DR/MDR-TB, panel B) unrelated to the Latin American Thoracic Association/European Respiratory Society/Brazilian Thoracic Association collaborative project and authored by researchers working in Brazil, Mexico, Peru, Colombia, or Argentina. IF: impact factor. 
between 2006 and 2015. The authors found that the number of studies on tuberculosis and MDR-TB increased from 4,460 and 279, respectively, in 2013 to 4,711 and 342 , respectively, in 2016 . They also ranked countries by their level of scientific production on the topic of MDR-TB: Peru ranked 13th, with 69 articles; Brazil ranked 18th, with 51; Mexico ranked 24th, with 36; Argentina ranked 31st, with 29; and Colombia ranked 37th, with 14. In the worldwide bibliometric analysis, original articles accounted for $71.3 \%$ of the articles, whereas review articles accounted for $9.6 \%$ and editorials accounted for $3.8 \%$. Despite the methodological differences between that study and ours (the former having used the Scopus database, having focused on MDR-TB, and not having limited the searches to journals with an impact factor), the overall production in the Latin American countries included in our study is quantitatively consistent with that reported by those authors. Given

Table 1. Articles unrelated to the Latin American Thoracic Association/European Respiratory Society/Brazilian Thoracic Association collaborative project, 2013-2018.

\begin{tabular}{cccc} 
Year & Pulmonary TB & DR/MDR-TB & Total \\
\hline 2013 & 75 & 33 & 108 \\
2014 & 86 & 32 & 118 \\
2015 & 67 & 40 & 107 \\
2016 & 90 & 32 & 132 \\
2017 & 60 & 41 & 114 \\
$2018^{\mathrm{a}}$ & 17 & 10 & 44 \\
Total & 395 & 188 & 583 \\
\hline
\end{tabular}

TB: tuberculosis; and DR/MDR-TB: drug-resistant/ multidrug-resistant tuberculosis. anly articles published in the first quarter of 2018.

Panel A) Pulmonary TB manuscripts

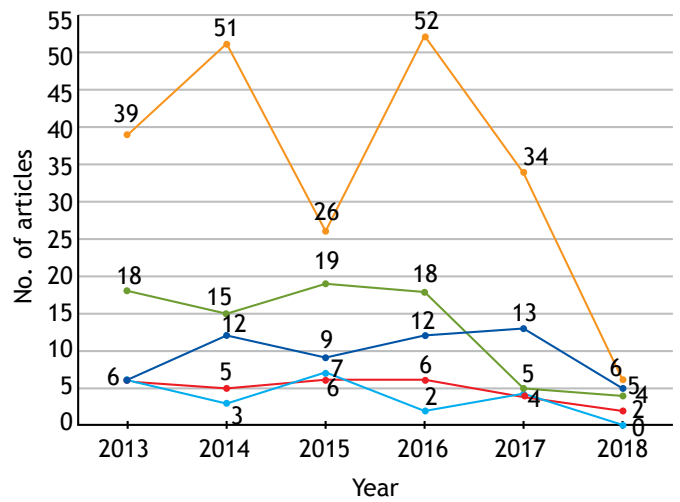

\begin{tabular}{|ll|c|c|}
\hline \multicolumn{3}{|c|}{ Total 2013-2018 } \\
\hline Countries & $\mathrm{N}$ & $\%$ \\
\hline Brazil & - & 208 & 52.7 \\
\hline Mexico & - & 79 & 20.0 \\
\hline Peru & - & 57 & 14.4 \\
\hline Colombia & - & 29 & 7.3 \\
\hline Argentina & - & 22 & 5.6 \\
\hline Total & & 395 & 100 \\
\hline
\end{tabular}

the continuous increase in the number of articles published over time, the number of articles published per year is comparable between the two studies. In terms of the types of articles, our findings were also similar: original articles were the most common type of articles, followed by review articles and editorials. One difference was related to the proportional distribution of the article types, original articles accounting for $96.5 \%$ of the articles identified in our study, compared with only $71.3 \%$ in the study conducted by Sweileh et al. ${ }^{(24)}$ In the latter study, one Latin American author (Becerra MC, from Peru) was among the top 20 authors publishing research on MDR-TB, having authored 29 articles during the period evaluated. That same author also ranked highly in our study. Nine of the top-ranked authors from the five countries we studied had an h-index $\geq 20$ (50 being the highest), confirming that high-quality research groups are active in the region. However, it should be borne in mind that some of the most highly ranked authors conduct research on a wide spectrum of tropical diseases other than tuberculosis and that their $\mathrm{h}$-indices therefore reflect their overall scientific production.

In the present study, we considered the articles in which at least one of the authors had an affiliation in one of the five Latin American countries selected. Therefore, articles in which the affiliation was outside those countries (e.g., Harvard University rather than the Peruvian Partners in Health Research Network for studies conducted in Peru) were not counted. As previously mentioned, we did not consider studies conducted in Haiti, because research projects in

Panel B) DR/MDR-TB manuscripts

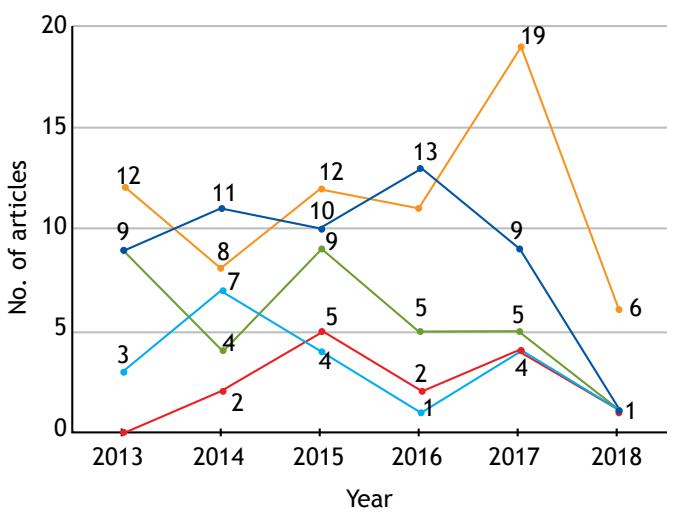

\section{Total 2013-2018}

\begin{tabular}{|ll|c|c|}
\hline Countries & $\mathrm{N}$ & $\%$ \\
\hline Brazil & - & 68 & 36.2 \\
\hline Peru & - & 53 & 28.2 \\
\hline Mexico & - & 33 & 17.6 \\
\hline Argentina & - & 20 & 10.6 \\
\hline Colombia & - & 14 & 7.4 \\
\hline Total & & $\mathbf{1 8 8}$ & $\mathbf{1 0 0}$ \\
\hline
\end{tabular}

Figure 2. Results of the searches for manuscripts on pulmonary tuberculosis (TB, panel A) and on drug-resistant/ multidrug-resistant tuberculosis (DR/MDR-TB, panel B) unrelated to the Latin American Thoracic Association/European Respiratory Society/Brazilian Thoracic Association collaborative project, by country. 
Table 2. Manuscript types and topics of the articles unrelated to the Latin American Thoracic Association/European Respiratory Society/Brazilian Thoracic Association collaborative project, 2013-2018. ${ }^{\text {a }}$

\begin{tabular}{|c|c|c|c|c|}
\hline \multirow{2}{*}{$\begin{array}{l}\text { Manuscript characteristic } \\
\text { Type }\end{array}$} & \multicolumn{2}{|c|}{ Pulmonary TB } & \multicolumn{2}{|c|}{ DR/MDR-TB } \\
\hline & $\mathrm{n}$ & $\%$ & $\mathrm{n}$ & $\%$ \\
\hline Original article ${ }^{b}$ & 381 & 96.5 & 182 & 96.8 \\
\hline Review article & 11 & 2.8 & 4 & 2.1 \\
\hline Editorial & 3 & 0.8 & 2 & 1.1 \\
\hline Total & 395 & 100 & 188 & 100 \\
\hline Topic & $\mathrm{n}$ & $\%$ & $\mathrm{n}$ & $\%$ \\
\hline Epidemiology/research & 140 & 35.4 & 61 & 32.4 \\
\hline Biochemistry/diagnosis & 93 & 23.5 & 51 & 27.1 \\
\hline Treatment/outcomes & 44 & 11.1 & 58 & 30.9 \\
\hline Genetics/immunology/vaccines & 118 & 29.9 & 18 & 9.6 \\
\hline Total & 395 & 100 & 188 & 100 \\
\hline
\end{tabular}

TB: tuberculosis; and DR/MDR-TB: drug-resistant/multidrug-resistant tuberculosis. ${ }^{\text {Ind }}$ (uded only the first quarter of 2018. ' Included all articles containing original data (full manuscripts, short reports, and letters).

Table 3. Top authors, in each country, of articles on pulmonary tuberculosis or drug-resistant/multidrug-resistant tuberculosis that were unrelated to the Latin American Thoracic Association/European Respiratory Society/Brazilian Thoracic Association collaborative project, as determined in the bibliometric analysis.

\begin{tabular}{|c|c|c|c|}
\hline $\begin{array}{l}\text { Country } \\
\text { Author }\end{array}$ & $\begin{array}{c}\text { Articles on pulmonary } \\
\text { TB or DR/MDR-TB }\end{array}$ & H-index ${ }^{a}$ & Cited documents $^{a}$ \\
\hline \multicolumn{4}{|l|}{ Argentina } \\
\hline Bottasso, Oscar A & 11 & 22 & 158 \\
\hline Ritacco, Viviana & 11 & 26 & 94 \\
\hline López, Beatriz & 10 & 15 & 43 \\
\hline Sasiain, María del Carmen & 9 & 17 & 68 \\
\hline Bay, María Luisa & 8 & 14 & 40 \\
\hline \multicolumn{4}{|l|}{ Brazil } \\
\hline Kritski, Afrânio Lineu & 27 & 28 & 186 \\
\hline Maciel, Ethel Leonor Noia & 16 & 17 & 98 \\
\hline Rossetti, Maria Lúcia Rosa & 15 & 20 & 86 \\
\hline Dietze, Reynaldo & 14 & 35 & 133 \\
\hline Trajman, Anete & 14 & 17 & 77 \\
\hline \multicolumn{4}{|l|}{ Colombia } \\
\hline Marín, Diana & 8 & 4 & 17 \\
\hline Robledo, Jaime & 8 & 18 & 70 \\
\hline Arbeláez, María Patricia & 6 & 11 & 34 \\
\hline Barrera, Luis Fernando & 5 & 15 & 32 \\
\hline García, Luis Fernando & 5 & 28 & 108 \\
\hline \multicolumn{4}{|l|}{ Mexico } \\
\hline Hernández-Pando, Rogelio & 32 & 50 & 312 \\
\hline Mata-Espinosa, Dulce & 20 & 9 & 32 \\
\hline Marquina-Castillo, Brenda & 14 & 9 & 27 \\
\hline Barrios-Payán, Jorge & 12 & 8 & 26 \\
\hline García-García, Lourdes & 11 & 28 & 115 \\
\hline Zenteno-Cuevas, Roberto & 11 & 8 & 32 \\
\hline \multicolumn{4}{|l|}{ Peru } \\
\hline Contreras, Carmen & 20 & 12 & 46 \\
\hline Lecca, Leonid & 19 & 8 & 38 \\
\hline Becerra, Mercedes C & 18 & 31 & 112 \\
\hline Coronel, Jorge & 16 & 12 & 39 \\
\hline Calderon, Roger & 12 & 6 & 18 \\
\hline Gotuzzo, Eduardo & 12 & 52 & 401 \\
\hline Seas, Ramos Carlos & 12 & 22 & 117 \\
\hline
\end{tabular}

TB: tuberculosis; and DR/MDR-TB: drug-resistant/multidrug-resistant tuberculosis. ${ }^{\text {aData }}$ from the Scopus citation database. 
Table 4. Comparative table showing studies related and unrelated to the Latin American Thoracic Association/European Respiratory Society/Brazilian Thoracic Association collaborative project.

\begin{tabular}{|c|c|c|c|c|c|c|c|c|}
\hline \multirow[t]{3}{*}{ Year } & \multicolumn{3}{|c|}{ PTB } & \multicolumn{3}{|c|}{ DR/MDR-TB } & \multicolumn{2}{|c|}{ PTB and DR/MDR-TB } \\
\hline & \multirow[t]{2}{*}{ Total } & \multicolumn{2}{|c|}{ ALAT/ERS/SBPT } & \multirow[t]{2}{*}{ Total } & \multicolumn{2}{|c|}{ ALAT/ERS/SBPT } & \multirow[t]{2}{*}{ Total } & \multirow{2}{*}{$\begin{array}{c}\text { ALAT/ERS/SBPT } \\
\text { Related }\end{array}$} \\
\hline & & Unrelated & Related & & Unrelated & Related & & \\
\hline 2016 & 92 & 90 & 2 & 40 & 32 & 8 & 132 & $10(7.5 \%)$ \\
\hline 2017 & 63 & 60 & 3 & 50 & 41 & 9 & 113 & $12(10.6 \%)$ \\
\hline $2018^{a}$ & 30 & 17 & 13 & 14 & 10 & 4 & 44 & $17(38.6 \%)$ \\
\hline Total & 185 & 167 & $18(9.7 \%)$ & 104 & 83 & $21(20.1 \%)$ & 289 & $39(13.5 \%)$ \\
\hline
\end{tabular}

PTB: pulmonary tuberculosis; DR/MDR-TB: drug-resistant/multidrug-resistant tuberculosis; ALAT: Asociación Latino Americana de Tórax (Latin American Thoracic Association); ERS: European Respiratory Society; and SBPT:

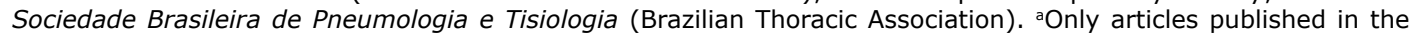
first quarter of 2018.

Panel A

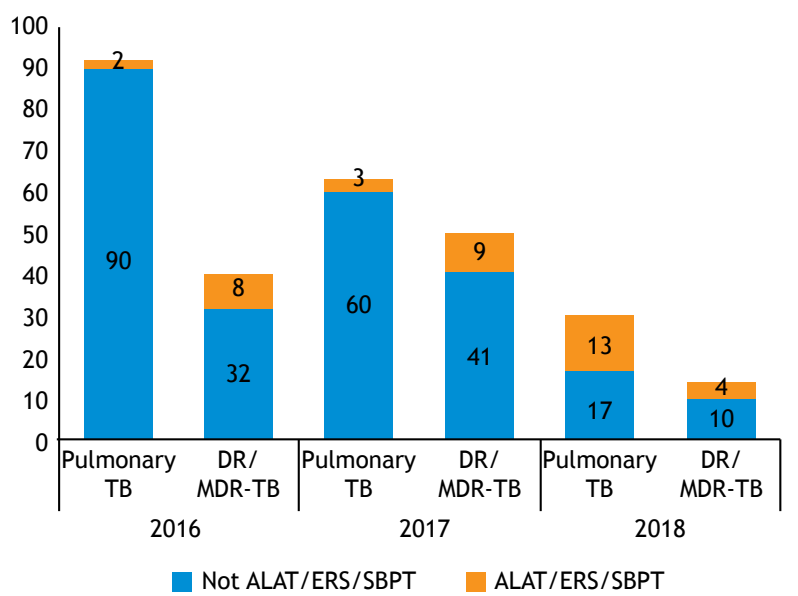

Panel B

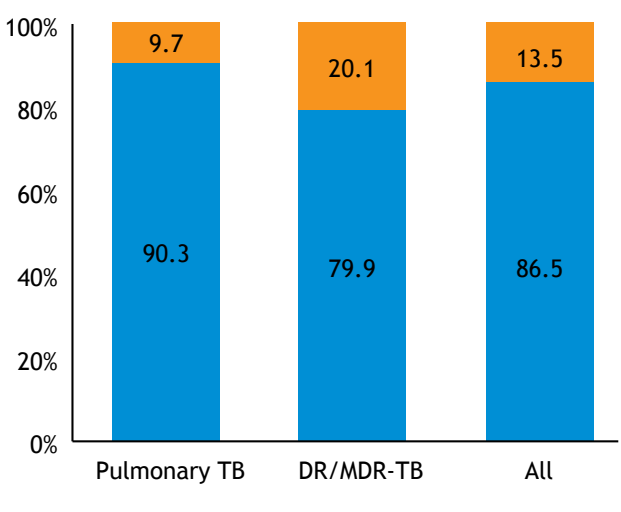

Not ALAT/ERS/SBPT

ALAT/ERS/SBPT

Figure 3. Impact of a collaborative project on the production of articles on pulmonary tuberculosis (TB) and drugresistant/multidrug-resistant tuberculosis (DR/MDR-TB) published in the 2016-2018 period*. Panel A compares the number of articles per year, and panel B presents the overall contribution of the project. ALAT: Asociación Latinoamericana de Tórax (Latin American Thoracic Association); ERS: European Respiratory Society; and SBPT: Sociedade Brasileira de Pneumologia e Tisiologia (Brazilian Thoracic Association). *Included only the first quarter of 2018.

that country are mainly funded by the United States government and because Haiti has not yet participated in any of the studies published as part of the ALAT/ ERS/SBPT project.

An indirect way of evaluating the quality of studies is by looking at the number and proportion of articles accepted in peer-reviewed journals with an impact factor. In the present study, articles were excluded if they were published in journals without an impact factor, as was the case for only $33(7.7 \%)$ of 428 articles on PTB and only $12(6.0 \%)$ of 200 articles on DR/MDR-TB. That suggests that the vast majority of such articles produced in Latin America have been published in high-quality journals.

The results of our study show how international collaborations are able to boost the quality and quantity of scientific production in Latin America. Examples of such collaborations are that between the Partners in Health initiative of Harvard University and the Peruvian National TB Program consortium, (20-23) as well as the internal collaboration in Brazil within the Brazilian Tuberculosis Research Network, which has allowed several international collaborations to be developed on the foundation of a well-designed national research plan. ${ }^{(14-19)}$

The ALAT/ERS/SBPT project allowed a research network involving five Latin American countries and Italy to be established in collaboration with the Maugeri Scientific Institute (Tradate, Italy). Particularly relevant are the scientific collaborations within this project involving four institutions in Mexico-the National Institute of Respiratory Diseases, in Mexico City; the Center for the Investigation, Prevention, and Treatment of Respiratory Infections, at the University Hospital of Monterrey; the Autonomous University of Nuevo León, in San Nicolás de los Garza; and the Mexican National TB Program-as well as four institutions in Brazil-the Oswaldo Cruz Foundation, in the city of Rio de Janeiro; the Federal University of Rio Grande do Sul, in Porto Alegre; the Brazilian Tuberculosis Research Network; and the Brazilian National Tuberculosis Control Program. Thus, the ALAT/ ERS/SBPT project not only involved three scientific medical associations but also worked with three universities and two national tuberculosis programs, with no funding at all. 
Table 5. Summary of all of the authors publishing studies related to the Latin American Thoracic Association/European Respiratory Society/Brazilian Thoracic Association collaborative project between 2016 and 2018. ${ }^{a}$

\begin{tabular}{|c|c|c|}
\hline Country & Author(s) & $\mathbf{n}$ \\
\hline \multirow[t]{2}{*}{ Argentina } & Palmero DJ & 2 \\
\hline & González Montaner P & 1 \\
\hline \multirow[t]{7}{*}{ Brazil } & Arbex MA, Dalcolmo M & 8 \\
\hline & Silva DR & 7 \\
\hline & Mello FCQ & 6 \\
\hline & Bonini EH, Carvalho ACC & 5 \\
\hline & Kritski AL & 3 \\
\hline & Alves TG, Borga L, Braga JU, Dockhorn F, Fandinho F, Rabahi MF, Rocha JL & 2 \\
\hline & $\begin{array}{l}\text { Arakaki-Sanchez D, Arbex FF, Augusto VM, Barbosa MS, Beraldi-Magalhães F, Cardoso CAA, } \\
\text { Cordeiro-Santos M, Dias NJD, Ferreira MD, Galesi VM, Kawakame Pirolla G, Martire TM, } \\
\text { Neves CPD, Pereira GR, Sant'Anna CC, Sanchez DA, Souza AB }\end{array}$ & 1 \\
\hline \multirow[t]{2}{*}{ Colombia } & Torres-Duque CA & 4 \\
\hline & Fuentes Z & 2 \\
\hline \multirow[t]{6}{*}{ Mexico } & Rendon A & 12 \\
\hline & Muñoz-Torrico M & 11 \\
\hline & Salazar-Lezama MA & 6 \\
\hline & Pérez-Padilla R & 3 \\
\hline & $\begin{array}{l}\text { Carrillo-Alduenda JL, Flores-Vergara H, García-Sancho C, Gayoso R, Martínez-Mendoza D, } \\
\text { Torres-Cruz A, Villareal-Velarde H }\end{array}$ & 2 \\
\hline & Martínez-Orozco JA, Millán MJM, Narváez-Diaz LA, Saavedra Herrera N, Segura-Del Pilar M & 1 \\
\hline \multirow[t]{3}{*}{ Peru } & Alarcón VA & 4 \\
\hline & Alarcón E, Manga S, Varga-Vasquez D & 3 \\
\hline & Bayona J, Becerra MC, Perales R, Reaño M & 1 \\
\hline
\end{tabular}

ancluded only the first quarter of 2018.

According to Sweileh et al., ${ }^{(24)}$ the Harvard University Partners in Health initiative and the Maugeri Scientific Institute are both in the top 10 most active institutions worldwide in terms of the number of published articles on MDR-TB. ${ }^{(3-6,25-59)}$ Additional examples of scientific collaboration identified in our study are those on basic research involving leading institutions in Mexico, Argentina, and Colombia, which are often funded by other international partners. ${ }^{(60-64)}$

It is noteworthy that the ALAT/ERS/SBPT project not only boosted the quality and quantity of scientific production in Latin America but also encouraged young investigators to publish for the first time (improving their academic records) while consolidating the publication records of several senior experts (Table 4). In addition, as previously mentioned, the collaboration did not receive any specific funding from any group or medical society.

Although comprehensive in its design, our study has several limitations. First, it covered only five Latin American countries, all with a high incidence of tuberculosis, notably excluding Haiti and thus not covering the whole WHO Region of the Americas. Therefore, the total scientific production in the region was not covered in this study. In addition, we chose to use "pulmonary TB" rather than "TB" as a search term, thus omitting a certain number of potentially relevant publications. However, that approach was useful in order to limit the number of papers dealing with extrapulmonary cases and including tuberculosis in absence of a main focus on the disease (there were several articles on animal tuberculosis or in which tuberculosis was mentioned only in the discussion without any data being provided). Nevertheless, the overall scientific production on tuberculosis in the region was likely underestimated. Furthermore, a direct comparison between the manuscripts that were related to the ALAT/ERS/SBPT project and those that were not was formally possible only for those dealing with DR/ MDR-TB. Moreover, although the main collaborations were described and the essential bibliometric analysis was performed, a detailed analysis of the scientific collaborations and of the citation counts of the articles identified was outside the scope of our study.

In conclusion, although we have shown that the scientific production in Latin America is of high quality, the number of publications seems low in comparison with that reported for other regions. ${ }^{(24)}$ We find it surprising that the national tuberculosis programs in the countries evaluated, despite having access to a large amount of data, have sponsored few published articles. More support is necessary in order to scale-up the existing research efforts in Latin America, which would strengthen the capacity of national tuberculosis programs to use their data to improve the prevention, diagnosis, and treatment of drug-susceptible and drug-resistant PTB in the respective countries, as well as to overcome the funding limitations and the language barriers. ${ }^{(24)}$

International collaboration among medical societies should be promoted as a proven effective way to boost scientific production in the field of tuberculosis in Latin America. Despite a lack of funding, such collaborations 
could support Pillar 3 (the intensified research and innovation portion) of the WHO "End TB Strategy".

\section{ACKNOWLEDGMENTS}

This study was conducted under the auspices of the ERS/ALAT and ERS/SBPT collaborative projects and the operational research plan of the WHO Collaborating Centre for Tuberculosis and Lung Diseases (Tradate, ITA-80, 2017-2020-GBM/RC/LDA), as well as those of the Global TB Network, hosted by the World Association for Infectious Diseases and Immunological Disorders.

\section{REFERENCES}

1. World Health Organization. Global tuberculosis report 2018. Geneva: World Health Organization; 2018.

2. World Health Organization [homepage on the Internet]. Geneva: World Health Organization; c2018 [cited 2018 Apr 19]. Tuberculosis data and statistics. Available from: http://www.who.int/tb/data/en/

3. Rendon A, Fuentes Z, Torres-Duque CA, Granado MD, Victoria $J$, Duarte $R$, et al. Roadmap for tuberculosis elimination in Latin American and Caribbean countries: a strategic alliance. Eur Respir J. 2016;48(5):1282-1287. https://doi.org/10.1183/13993003.015492016

4. Torres-Duque CA, Fuentes Alcalá ZM, Rendón A, Migliori GB. Roadmap for Tuberculosis Elimination in Latin America and the Caribbean. Arch Bronconeumol. 2018;54(1):7-9. https://doi. org/10.1016/j.arbres.2017.07.004

5. Duarte R, Silva DR, Rendon A, Alves TG, Rabahi MF, Centis R, et al. Eliminating tuberculosis in Latin America: making it the point. J Bras Pneumol. 2018;44(2):73-76. https://doi.org/10.1590/s180637562017000000449

6. Duarte R, Migliori GB, Zumla A, Cordeiro CR. Strengthening tuberculosis control to advance towards elimination: The 2018 Rev. Port. Pneumol. (RPP) TB Series. Pulmonology. 2018;24(2):67-68. https://doi.org/10.1016/.j.pulmoe.2018.01.002

7. Lönnroth K, Migliori GB, Abubakar I, D’Ambrosio L, de Vries G, Diel $R$, et al. Towards tuberculosis elimination: an action framework for low-incidence countries. Eur Respir J. 2015;45(4):928-52. https:// doi.org/10.1183/09031936.00214014

8. Voniatis C, Migliori GB, Voniatis M, Georgiou A, D'Ambrosio $L$, Centis $R$, et al. Tuberculosis elimination: dream or reality? The case of Cyprus. Eur Respir J. 2014:44(2):543-6. https://doi. org/10.1183/09031936.00044314

9. Al Yaquobi F, Al-Abri S, Al-Abri B, Al-Abaidani I, Al-Jardani A, D'Ambrosio L, et al. Tuberculosis elimination: a dream or a reality? The case of Oman. Eur Respir J. 2018;51(1). pii: 1702027. https:// doi.org/10.1183/13993003.02027-2017

10. Pan American Health Organization [homepage on the Internet]. Washington, DC: Pan American Health Organization. 52nd Directing Council. 65th session of the Regional Committee for the Americas [updated 2013 Sep 1; cited 2018 Jun 22]. Strategic Plan of the Pan American Health Organization 2014-2019. [Adobe Acrobat document; 147p.]. Available from: https://www.paho.org/ hq/dmdocuments/2014/OD345-e.pdf

11. Pan American Health Organization [homepage on the Internet] Washington, DC: Pan American Health Organization. 54th Directing Council. 67th session of the Regional Committee for the Americas [updated 2015 Oct 2; cited 2018 Jun 22]. Plan of action for the prevention and control of tuberculosis. [Adobe Acrobat document; 24p.]. Available from: https://www.paho.org/hq/ dmdocuments/2015/CD54-11-e.pdf

12. Brasil. Ministério da Saúde. [homepage on the Internet] Brasília: Ministério da Saúde. Secretaria de Vigilância em Saúde. Departamento de Vigilância das Doenças Transmissíveis [cited 2018 Jun 22]. Brasil Livre da Tuberculose: Plano Nacional pelo Fim da Tuberculose como Problema de Saúde Pública 2017. [Adobe Acrobat document; 54p.]. Available from: http://portalarquivos2. saude.gov.br/images/pdf/2017/junho/29/plano_nacional_tb_web. pdf

13. Moher D, Liberati A, Tetzlaff J, Altman DG; PRISMA Group. Preferred reporting items for systematic reviews and metaanalyses: the PRISMA statement. PLoS Med. 2009;6(7): e1000097. https://doi.org/10.1371/journal.pmed.1000097

14. David SG, Lovero KL, Pombo March MFB, Abreu TG, Ruffino Netto A, Kritski AL, et al. A comparison of tuberculosis diagnostic systems in a retrospective cohort of HIV-infected children in Rio de Janeiro, Brazil. Int J Infect Dis. 2017;59:150-155. https://doi. org/10.1016/j.ijid.2017.01.038
15. de O Souza Filho JB, de Seixas JM, Galliez R, de Bragança Pereira $B$, de $\mathrm{Q}$ Mello FC, Dos Santos AM, et al. A screening system for smear-negative pulmonary tuberculosis using artificial neural networks. Int J Infect Dis. 2016;49:33-9. https://doi.org/10.1016/j. ijid.2016.05.019

16. Mesquita ED, Gil-Santana L, Ramalho D, Tonomura E, Silva EC, Oliveira MM, et al. Associations between systemic inflammation, mycobacterial loads in sputum and radiological improvement after treatment initiation in pulmonary TB patients from Brazil: a prospective cohort study. BMC Infect Dis. 2016;16:368. https://doi. org/10.1186/s12879-016-1736-3

17. de Assunção TM, Batista EL Jr, Deves C, Villela AD, Pagnussatti VE, de Oliveira Dias AC, et al. Real time PCR quantification of viable Mycobacterium tuberculosis from sputum samples treated with propidium monoazide. Tuberculosis (Edinb). 2014;94(4):421-7. https://doi.org/10.1016/j.tube.2014.04.008

18. Bastos ML, Cosme LB, Fregona G, do Prado TN, Bertolde Al, Zandonade $\mathrm{E}$, et al. Treatment outcomes of MDR-tuberculosis patients in Brazil: a retrospective cohort analysis. BMC Infect Dis. 2017;17(1):718. https://doi.org/10.1186/s12879-017-2810-1

19. Vasconcelos KA, Frota SMMC, Ruffino-Netto A, Kritski AL. Sequential analysis as a tool for detection of amikacin ototoxicity in the treatment of multidrug-resistant tuberculosis. J Bras Pneumol. 2018;44(2):85-92. https://doi.org/10.1590/s180637562016000000312

20. Odone A, Calderon R, Becerra MC, Zhang Z, Contreras CC, Yataco $R$, et al. Acquired and Transmitted Multidrug Resistant Tuberculosis: The Role of Social Determinants. PLoS One. 2016;11(1):e0146642. https://doi.org/10.1371/journal.pone.0146642

21. Kurbatova EV, Cegielski JP, Lienhardt C, Akksilp R, Bayona J, Becerra MC, et al. Sputum culture conversion as a prognostic marker for end-of-treatment outcome in patients with multidrugresistant tuberculosis: a secondary analysis of data from two observational cohort studies. Lancet Respir Med. 2015;3(3):201-9. https://doi.org/10.1016/S2213-2600(15)00036-3

22. Franke MF, Appleton SC, Mitnick CD, Furin JJ, Bayona J, Chalco $\mathrm{K}$, et al. Aggressive regimens for multidrug-resistant tuberculosis reduce recurrence. Clin Infect Dis. 2013;56(6):770-6. https://doi. org/10.1093/cid/cis1008

23. Chiang SS, Starke JR, Miller AC, Cruz AT, Del Castillo H, Valdivia WJ, et al. Baseline Predictors of Treatment Outcomes in Children With Multidrug-Resistant Tuberculosis: A Retrospective Cohort Study. Clin Infect Dis. 2016;63(8):1063-71. https://doi.org/10.1093/ cid/ciw489

24. Sweileh WM, AbuTaha AS, Sawalha AF, Al-Khalil S, Al-Jabi SW, Zyoud SH. Bibliometric analysis of worldwide publications on multi-, extensively, and totally drug - resistant tuberculosis (20062015). Multidiscip Respir Med. 2017;11:45. https://doi.org/10.1186/ s40248-016-0081-0

25. Silva DR, de Queiroz Mello FC, Kritski A, Dalcolmo M, Zumla A, Migliori GB. Tuberculosis series. J Bras Pneumol. 2018;44(2):71-72. https://doi.org/10.1590/s1806-37562018000020001

26. Ferreira MD, Neves CPD, Souza AB, Beraldi-Magalhães F, Migliori $G B$, Kritski $A L$, et al. Predictors of mortality among intensive care unit patients coinfected with tuberculosis and HIV. J Bras Pneumol. 2018;44(2):118-124. https://doi.org/10.1590/s180637562017000000316

27. Carvalho AC, Cardoso CAA, Martire TM, Migliori GB, Couto Sant'Anna CC. Epidemiological aspects, clinical manifestations, and prevention of pediatric tuberculosis from the perspective of the End TB Strategy. J Bras Pneumol. 2018;44(2):134-144. https://doi org/10.1590/s1806-37562017000000461

28. Silva DR, Dalcolmo M, Tiberi S, Arbex MA, Munoz-Torrico $M$, Duarte $R$, et al. New and repurposed drugs to treat multidrug- and extensively drug-resistant tuberculosis. J Bras 
Pneumol. 2018;44(2):153-160. https://doi.org/10.1590/s180637562017000000436

29. Silva DR, Muñoz-Torrico M, Duarte R, Galvão T, Bonini EH, Arbex FF, et al. Risk factors for tuberculosis: diabetes, smoking, alcoho use, and the use of other drugs. J Bras Pneumol. 2018;44(2):145152. https://doi.org/10.1590/s1806-37562017000000443

30. Chalmers JD, Aksamit T, Carvalho ACC, Rendon A, Franco I. Nontuberculous mycobacterial pulmonary infections. Pulmonology. 2018;24(2):120-131. https://doi.org/10.1016/j.pulmoe.2017.12.005

31. Carvalho I, Goletti D, Manga S, Silva DR, Manissero D, Migliori GB. Managing latent tuberculosis infection and tuberculosis in children. Pulmonology. 2018;24(2):106-114. https://doi.org/10.1016/j. rppnen.2017.10.007

32. Munoz-Torrico M, Salazar MA, Millán MJM, Martínez Orozco JA Narvaez Diaz LA, Segura Del Pilar M, et al. Eligibility for the shorte regimen for multidrug-resistant tuberculosis in Mexico. Eur Respir J 2018;51(3). pii: 1702267. https://doi.org/10.1183/13993003.022672017

33. Tiberi $S$, Muñoz-Torrico $M$, Duarte R, Dalcolmo M, D'Ambrosio L, Migliori GB. New drugs and perspectives for new antituberculosis regimens. Pulmonology. 2018;24(2):86-98. https://doi org/10.1016/j.rppnen.2017.10.009

34. García-Basteiro AL, DiNardo A, Saavedra B, Silva DR, Palmero $D$, Gegia $M$, et al. Point of care diagnostics for tuberculosis Pulmonology. 2018;24(2):73-85. https://doi.org/10.1016/j. rppnen.2017.12.002

35. Silva DR, Sotgiu G, D'Ambrosio L, Pereira GR, Barbosa MS, Dias NJD, et al. Diagnostic performances of the Xpert MTB/RIF in Brazil. Respir Med. 2018;134:12-15. https://doi.org/10.1016/j. rmed.2017.11.012

36. Rendon A, Centis R, Zellweger JP, Solovic I, Torres-Duque CA Robalo Cordeiro C, et al. Migration, TB control and elimination: Whom to screen and treat. Pulmonology. 2018;24(2):99-105. https://doi.org/10.1016/j.rppnen.2017.11.007

37. Duarte R, Lönnroth K, Carvalho C, Lima F, Carvalho ACC, MuñozTorrico $M$, et al. Tuberculosis, social determinants and comorbidities (including HIV). Pulmonology. 2018;24(2):115-119. https://doi.org/10.1016/j.rppnen.2017.11.003

38. D'Ambrosio L, Bothamley G, Caminero Luna JA, Duarte $R$ Guglielmetti L, Muñoz Torrico M, et al. Team approach to manage difficult-to-treat TB cases: Experiences in Europe and beyond. Pulmonology. 2018;24(2):132-141. https://doi.org/10.1016/j. rppnen.2017.10.005

39. Amicosante M, D'Ambrosio L, Munoz M, Mello FCQ, Tebruegge $M$, Chegou NN, et al. Current use and acceptability of novel diagnostic tests for active tuberculosis: a worldwide survey. Bras Pneumol. 2017;43(5):380-392. https://doi.org/10.1590/s180637562017000000219

40. D'Ambrosio L, Centis R, Tiberi S, Tadolini M, Dalcolmo M Rendon $A$, et al. Delamanid and bedaquiline to treat multidrugresistant and extensively drug-resistant tuberculosis in children: a systematic review. J Thorac Dis. 2017;9(7):2093-2101. https://doi. org/10.21037/jtd.2017.06.16

41. Borisov SE, Dheda K, Enwerem M, Romero Leyet R, D'Ambrosio $L$, Centis $R$, et al. Effectiveness and safety of bedaquilinecontaining regimens in the treatment of MDR- and XDR-TB: a multicentre study. Eur Respir J. 2017;49(5). pii: 1700387. https:// doi.org/10.1183/13993003.00387-2017

42. Dalcolmo M, Gayoso R, Sotgiu G, D'Ambrosio L, Rocha JL, Borga $L$, et al. Resistance profile of drugs composing the "shorter" regimen for multidrug-resistant tuberculosis in Brazil, 2000-2015. Eur Respir J. 2017;49(4). pii: 1602309. https://doi org/10.1183/13993003.02309-2016

43. Dalcolmo M, Gayoso R, Sotgiu G, D'Ambrosio L, Rocha JL, Borga $L$, et al. Effectiveness and safety of clofazimine in multidrugresistant tuberculosis: a nationwide report from Brazil. Eur Respir J. 2017;49(3). pii: 1602445

44. Tiberi S, Buchanan R, Caminero JA, Centis R, Arbex MA, Salazar $M$, et al. The challenge of the new tuberculosis drugs. Presse Med. 2017:46(2 Pt 2):e41-e51.

45. Sotgiu G, Dara M, Centis R, Matteelli A, Solovic I, Gratziou C, et al. Breaking the barriers: Migrants and tuberculosis. Presse Med. 2017;46(2 Pt 2):e5-e11. https://doi.org/10.1016/.lpm.2017.01.013

46. Tiberi S, Carvalho AC, Sulis G, Vaghela D, Rendon A, Mello FC et al. The cursed duet today: Tuberculosis and HIV-coinfection. Presse Med. 2017;46(2 Pt 2):e23-e39. https://doi.org/10.1016/j.
Ipm.2017.01.017

47. Muñoz-Torrico $M$, Caminero-Luna J, Migliori GB, D'Ambrosio $L$, Carrillo-Alduenda JL, Villareal-Velarde $H$, et al. Diabetes is Associated with Severe Adverse Events in Multidrug-Resistant Tuberculosis. Arch Bronconeumol. 2017;53(5):245-250. https://doi. org/10.1016/.jarbr.2016.10.003

48. Muñoz-Torrico M, Caminero Luna J, Migliori GB, D'Ambrosio $\mathrm{L}$, Carrillo-Alduenda JL, Villareal-Velarde $\mathrm{H}$, et al. Comparison of bacteriological conversion and treatment outcomes among MDRTB patients with and without diabetes in Mexico: Preliminary data. Rev Port Pneumol (2006). 2017;23(1):27-30

49. Tiberi S, Scardigli A, Centis R, D'Ambrosio L, Muñoz-Torrico M Salazar-Lezama MÁ, et al. Classifying new anti-tuberculosis drugs: rationale and future perspectives. Int J Infect Dis. 2017;56:181-184. https://doi.org/10.1016/j.jiji.2016.10.026

50. Rendon A, Centis R, D'Ambrosio L, Migliori GB. WHO strategies for the management of drug-resistant tuberculosis. Arch Bronconeumol. 2017;53(3):95-97. https://doi.org/10.1016/j. arbres.2016.07.015

51. Manga S, Perales R, Rea-o M, D'Ambrosio L, Migliori GB, Amicosante M. Performance of a lateral flow immunochromatography test for the rapid diagnosis of active tuberculosis in a large multicentre study in areas with different clinical settings and tuberculosis exposure levels. J Thorac Dis. 2016;8(11):3307-3313. https://doi. org/10.21037/jtd.2016.11.51

52. Rendon A, Tiberi S, Scardigli A, D'Ambrosio L, Centis R, Caminero $\mathrm{JA}$, et al. Classification of drugs to treat multidrug-resistant tuberculosis (MDR-TB): evidence and perspectives. J Thorac Dis 2016;8(10):2666-2671. https://doi.org/10.21037/jtd.2016.10.14

53. Muñoz-Torrico $M$, Rendon $A$, Centis $R$, D'Ambrosio $L$, Fuentes $Z$, Torres-Duque $C$, et al. Is there a rationale for pulmonary rehabilitation following successful chemotherapy for tuberculosis? J Bras Pneumol. 2016;42(5):374-385. https://doi.org/10.1590/ S1806-37562016000000226

54. Sotgiu G, Tiberi S, D'Ambrosio L, Centis R, Alffenaar JW, Caminero $\mathrm{JA}$, et al. Faster for less: the new "shorter" regimen for multidrugresistant tuberculosis. Eur Respir J. 2016;48(5):1503-1507. https:// doi.org/10.1183/13993003.01249-2016

55. Mitnick CD, White RA, Lu C, Rodriguez CA, Bayona J, Becerra $M C$, et al. Multidrug-resistant tuberculosis treatment failure detection depends on monitoring interval and microbiologica method. Eur Respir J. 2016;48(4):1160-1170. https://doi. org/10.1183/13993003.00462-2016

56. Arbex MA, Bonini EH, Kawakame Pirolla G, D'Ambrosio L, Centis $R$, Migliori GB. Effectiveness and safety of imipenem/clavulanate and linezolid to treat multidrug and extensively drug-resistant tuberculosis at a referral hospital in Brazil. Rev Port Pneumol (2006). 2016;22(6):337-341. https://doi.org/10.1016/j.rppnen.2016.06.006

57. Tiberi S, Sotgiu G, D'Ambrosio L, Centis R, Abdo Arbex M, Alarcon Arrascue $E$, et al. Comparison of effectiveness and safety of imipenem/clavulanate- versus meropenem/clavulanate-containing regimens in the treatment of MDR- and XDR-TB. Eur Respir J 2016;47(6):1758-66. https://doi.org/10.1183/13993003.00214-2016

58. Tiberi S, Payen MC, Sotgiu G, D'Ambrosio L, Alarcon Guizado $V$, Alffenaar JW, et al. Effectiveness and safety of meropenem/ clavulanate-containing regimens in the treatment of MDRand XDR-TB. Eur Respir J. 2016;47(4):1235-43. https://doi. org/10.1183/13993003.02146-2015

59. Tiberi S, Sotgiu G, D'Ambrosio L, Centis R, Arbex MA, Alarcon Arrascue $E$, et al. Effectiveness and Safety of ImipenemClavulanate Added to an Optimized Background Regimen (OBR) Versus OBR Control Regimens in the Treatment of MultidrugResistant and Extensively Drug-Resistant Tuberculosis. Clin Infect Dis. 2016;62(9):1188-90. https://doi.org/10.1093/cid/ciw088

60. Balboa L, Barrios-Payan J, González-Domínguez E, Lastrucci C, Lugo-Villarino G, Mata-Espinoza $D$, et al. Diverging biological roles among human monocyte subsets in the context of tuberculosis infection. Clin Sci (Lond). 2015;129(4):319-30. https://doi. org/10.1042/CS20150021

61. Bini El, D'Attilio L, Marquina-Castillo B, Mata-Espinosa D, Díaz $A$, Marquez-Velasco $R$, et al. The implication of pro-inflammatory cytokines in the impaired production of gonadal androgens by patients with pulmonary tuberculosis. Tuberculosis (Edinb). 2015;95(6):701-706. https://doi.org/10.1016/.tube.2015.06.002

62. Bini El, Mata Espinosa D, Marquina Castillo B, Barrios Payán J Colucci $D$, Cruz AF, et al. The influence of sex steroid hormones in the immunopathology of experimental pulmonary tuberculosis. 
PLoS One. 2014;9(4):e93831. https://doi.org/10.1371/journal. pone.0093831

63. Hernández-Pando R, Barrios-Payán J, Mata-Espinosa D Marquina-Castillo B, Hernández-Ramírez D, Bottasso OA, et al. The Role of High Mobility Group Box 1 Protein (HMGB1) in the Immunopathology of Experimental Pulmonary Tuberculosis. PLoS One. 2015;10(7):e0133200. https://doi.org/10.1371/journal. pone. 0133200

64. Rodríguez JE, Ramírez AS, Salas LP, Helguera-Repetto C, Gonzalez$y$-Merchand J, Soto CY, et al. Transcription of genes involved in sulfolipid and polyacyltrehalose biosynthesis of Mycobacterium tuberculosis in experimental latent tuberculosis infection. PLoS One. 2013;8(3):e58378. https://doi.org/10.1371/journal. pone. 0058378 